\title{
Recessive Ataxia in Acadians and "Cajuns"
}

\author{
A. Barbeau, M. Roy, M. Sadibelouiz, M.A. Wilensky*
}

\begin{abstract}
The physician exposed to a large number of patients with a recessive form of ataxia, will occasionally observe slower progression forms which lack many of the severe features or cardinal symptoms of Friedreich's disease. We have studied 31 such cases in Acadians of the Maritime Provinces of Canada, and in their separated "cousins" from Louisiana, now called "Cajuns". These patients are compared to a consecutive series of 22 Friedreich's disease cases in French Canada.

It is shown that the age of onset is slightly later, but the progression much slower and the age at death older in the Acadian patients. These cases develop signs of pyramidal and posterior column involvement gradually and later than the classical Friedreich. As a result, pes cavus and scoliosis are less marked, as well as muscle weakness and cardiomyopathy. On the other hand, the rate of progression of areflexic ataxia, the "core disease", is identical in both groups. The main difference in progression rates of the disorders occurs after 10-12 years of evolution, thus after the period of hormono-ponderal growth.

These differences, coupled to the diverging genetic and genealogical backgrounds, are sufficiently large for the presumption of distinct disorders. Whether they are due to allelic mutations, linked but different genes, genes affecting the same metabolic pathway, but elsewhere or to completely distinct entities, will have to be left to further studies, but their existence in completely different populations and milieux is worthy of report.
\end{abstract}

RÉSUMÉ: Le médecin exposé à l'étude d'un grand nombre de patients ataxiques à hérédité récessive rencontre à l'occasion des formes de la maladie à évolution lente où il semble manquer plusieurs des caractéristiques sévères et des symptômes cardinaux de la maladie de Friedreich. Nous avons étudié 31 tels malades chez des Acadiens des Provinces Maritimes du Canada et chez leurs "cousins" séparés de la Louisiane, que l'on dénomme les "Cajuns". Ces malades sont comparés à 22 patients vus consécutivement au Canada français et souffrant de la maladie de Friedreich.

Nous démontrons que l'âge de début est légèrement plus tardif, alors que la progression est beaucoup plus lente et l'âge au décès plus élevé chez les patients acadiens. Ces malades développent des signes d'atteinte pyramidale et des cordons postérieurs graduellement et beaucoup plus tardivement que le Friedreich classique. Conséquemment le pes cavus et la scoliose sont moins marqués, ainsi que la faiblesse musculaire et la cardiomyopathie. Par contre la vitesse de progression de l'ataxie aréflexique, qui constitute la maladie centrale, est identique dans les deux groupes. La principale différence dans le taux de progression des deux entités se produit après 10-12 ans d'évolution, donc après la période de croissance hormono-pondérale.

Ces différences, liées aux divergences génétiques et généalogiques, sont suffisamment importantes pour permettre l'hypothèse de l'existence de deux désordres distincts. Que ces désordres résultent de mutations alléliques, de gènes différents mais liés, d'anomalies dans la même chaîne métabolique ou d'entités distinctes, devra être le sujet d'études plus poussées, mais qui sont justifiées par l'existence de cette nouvelle forme de maladie dans des populations et milieux totalement distincts.

Can. J. Neurol. Sci. 1984; 11:526-533

Every clinician who has had the privilege of examining large numbers of cases of Friedreich's disease, has encountered subjects or even kindreds who did not fit the rigid criteria previously outlined for this disease (Geoffroy et al., 1976). These cases differed from the more "classical" ones in age of onset, in speed of progression of the illness, or in the absence or low incidence of some of the cardinal signs. Because of the notoriously high variability of presentations in inherited ataxias, and because these cases are relatively rare and sparsely distributed, over the years it has been difficult to resolve the problem of heterogeneity versus variability in expression.
Harding (1981) described a form of "recessive ataxia" with retained tendon reflexes which was clearly a distinct entity from Friedreich's disease. In 1980 while studying the cartography of ataxic syndromes in Quebec (Barbeau, 1980), we recognized a similar entity which we had called the "Matane" type of recessive ataxia, from the geographic isolate where we found it. In the same study we also identified a form of Friedreich's ataxia of rapid progression and early onset: the "Rimouski type". This was described in detail in another paper (Bouchard et al., 1979). At the other end of the spectrum were a number of patients with most of the classical features of Friedreich, but a

From the Clinical Research Institute of Montreal and Tulane University, New Orleans, LA.( $\left.{ }^{*}\right)$.

Request reprints for the complete supplement (Phase 3, Part 3) to: Prof. André Barbeau, Clinical Research Institute of Montreal, 110 Pine Avenue West, Montreal, Quebec, Canada H2W IR7 
definitely slower course with survival into the 50 's, thus at least 15 years later than cases of Friedreich's disease. Some of these patients had evidence of severe neuropathies and were first called "Recessive Roussy-Levy Syndrome" or Group II a (Geoffroy et al., 1976). It now appears that these terms are misnomers or that they create confusion. They should therefore be abandonned.

A majority of the French Canadian patients with this slowly progressive disorder appeared to originate in Acadia, or to be descendants of Acadian families from New Brunswick or the adjoining areas of the Baie des Chaleurs. This was the reason for the term "Acadian Ataxia" which we used (Barbeau, 1980) to designate this special form of recessive ataxia. Because the Acadians derive from a different stock of Frenchmen than most Quebécois, we sensed that this observation may help us in separating the two syndromes, if they were indeed distinct. Moreover Acadians have had a sad history of forced migrations and it would be useful to study the disease in geographically distant isolates from the same source to identify genetic traits as opposed to environmentally induced artefacts.

\section{SUMMARY OF ACADIAN HISTORY}

"Acadia", in geographical terms, used to include the territory now known as Nova Scotia, New Brunswick, Cape Breton Island and Prince Edward Island in Canada. Visited for centuries by fishermen from many countries, Acadia was first colonized in 1604 by the Frenchmen De Monts, Champlain and Poutrincourt. Of interest, it is only in 1607 that Jamestown in Virginia was established, in 1608 that Champlain founded Quebec, in 1620 that the Pilgrim Fathers landed at Plymouth Rock, and in 1621 that the Dutch built New Amsterdam, later to be New York.

Acadia, a French colony, was situated very close to the English settlements of Massachussets and it is not surprising that friction should develop between the two groups. In fact many attempts at occupation by the English occured (1613, $1654,1690,1710)$, but they were usually pushed back by soldiers and settlers encamped around Port-Royal (Annapolis Royal). Despite English rule from 1654 to 1671 , by 1713 when the colony was ceded to England (Treaty of Utrecht), there were 2,500 Frenchmen living in Acadia. Most of the pioneers had been born in the French provinces of Vienne and Anjou, and many of the early settlers were in fact from the village of Aulnay, in Loudunais. They decided to remain in Acadia, despite the new rulers, but most refused to swear allegiance to the king. Consequently they were declared "French Neutrals" by governor Philipps in 1730 and permitted to stay only without arms. The population grew rapidly during the following two decades until the arrival in 1749 of Edward Cornwallis as governor of Nova Scotia. Cornwallis abolished all previous privileges granted to the Acadians unless they joined the Protestant faith and swore proper allegiance to the king of England. This was the start of important emigration movements from Nova Scotia to Cape Breton Island and New Brunswick. In 1755, the decision was taken by governor Lawrence to chase all remaining Frenchmen and Acadians away from this British colony. This is what is called "Le Grand Dérangement des Acadiens" (The Great Deportation).

Between 1749 and 1752, of a total of 18,000 Acadians, nearly 6,000 had already left Nova Scotia, and many thousands more did so in early 1755 . On July 31,1755 the Deportation order was signed and in the course of 5 months (August to December), most of the remaining population was moved to ships and taken abroad, often after families were broken up. The villages were burned and destroyed and all lands confiscated. Thus 7,000 Acadians were dispersed to various Anglo-American colonies, the others to England, Canada and France: 2,000 went to Massachusetts; 700 to Connecticut; 300 to New York; 500 to Pennsylvania; 1,000 to Maryland; 1,200 to Virginia; 500 to North Carolina; 500 to South Carolina and 400 to Georgia. Most of these colonies had not been warned of the arrival of the Acadians, and therefore the deportees were not welcomed, more so because of their language and religion. In these colonies their condition thus remained usually bad.

From Pennsylvania, Maryland, Virginia, Georgia and the Carolinas, many of the survivors, after the Treaty of Paris (1763), eventually went to the Antilles or migrated directly to Louisiana, their final landing place. It is recalled that Louisiana had previously been a French colony and had attracted, by its climate and wealth, many Frenchmen and Canadians, under the leadership of famous explorers and priests (La Salle, Jolliet, Marquette, Le Moyne d'Iberville, Bienville). From 1777 to 1788 , more than 3,000 Acadians left France where they had been deported, to rejoin relatives and friends in Louisiana, thus forming the nucleus of a fast growing population of settlers.

Most of the Acadian population, nowadays, is concentrated in the South-West portion of the State of Louisiana, a rich land with good climate and the famous "bayous". As is well known, their traditions have blended with those of the Spaniards and of the black slaves to create what is now known as the "Cajun" culture (Arsenault, 1978). The word "Cajun" is a phonetic deformation of "Acadian".

\section{SUBJECTS AND METHODS}

In the course of previous field trips to the Gaspé Peninsula and to the shores of Baie des Chaleurs, our group had been able to study a total of 14 ataxic patients of Acadian origin. This cluster of patients with an apparently much slower type of Friedreich's Ataxia attracted our attention. They were studied thoroughly with what was at the time the first version of our Research Protocole for Ataxia (Pourcher and Barbeau, 1980). This version encompassed most of the items presently listed, but did not properly calibrate muscle weakness.

The senior authors had previously learnt from the late Professor H.W. Kloepfer of New Orleans of the existence of a cluster of ataxic subjects among the "Cajun" population of South-Western Louisiana. It was thus with pleasure that they accepted an invitation to join an Ataxia Clinic held in Lafayette, Louisiana, in February 1983. At that Clinic we examined 28 ataxic patients, 17 of which were of Acadian descent. Each patient was evaluated according to the final Ataxia Protocole. In this protocole 46 items are objectively calibrated on a scale of 0 to 3: 0 is normal; 1: mild; 2: moderate; 3: severe disability or deviation from normal. These items are grouped into 6 categories: cranial nerves (max. score 18); incoordination (42); tone (18); reflexes (24); peripheral signs (24), and muscle strength (12, distal and 12,proximal). For computer analysis (Vax 750 computer) using the Statistical Package for the Social Sciences (SPSS) program of the University of Montreal, scores for the measurement of individual signs were utilized. In addition, "System Complex" scores were calculated for "Periphery" (P), "Incoordination" 
(C) and "Spasticity" (S): the "Periphery Score" (max. 45) included items 27 to 32 if negative (decreases in reflexes), items 35 to 37 (atrophy and fasciculations), 41 and 42 (vibratory sense) and 43 to 46 (decreased distal muscle strength). The "Incoordination Score" (max. 42) included items 7 to 20 (gait, Romberg, finger to nose, heel to knee, adiodocokinesia, postural tremor, tapping and drawing a spiral with each hand). Finally the "Spasticity Score" (max. 42) included items 21 to 24 (if increased tone), 27 to 34 (increased reflexes, plantars), and 47, 48 (clonus). Each of these Symptom Complex Scores was normalized to $100 \%$.

As a control group, we studied a consecutive series of 22 cases of well defined Friedreich's disease in French Canada. These patients were seen at the Ataxia Clinic of the Clinical Research Institute of Montreal, using the same evaluation protocole.

\section{Results}

\section{A. The Patients}

Three groups of patients were thus studied by us and compared with each other. One, serving as control, consisted of 22 Friedreich's disease victims answering to all the classical criteria previously described by Geoffroy et al. (1976) for that disease. All were from the Province of Quebec and none from Acadian origin or from the Maritime Provinces. The second group was studied in 1981 in New Brunswick; except for 3 patients followed regularly in Montreal, they were not seen again by the authors, although regular mail reports were received. Finally 17 other patients were examined during a single clinic in 1983 in Lafayette, Louisiana.

As seen in Table 1, there were no significant differences between the patients from New Brunswisk and those from Louisiana, although they were separated by hundreds of miles, seven generations and 200 years from their common ancestors in Acadia. This is a most significant point because it makes it evident that "Acadian Ataxia", if it exists as an entity, is related to genetic factors rather than to reasons of environment. Because the two groups are indistinguishable, henceforth we will study them together when comparing this form of recessive ataxia with Friedreich's disease.

\section{(a) Sex}

The 22 Friedreich's disease patients examined included 10 men and 12 women, thus approximately the same distribution as in Louisiana ( 7 men, 10 women), while the ratio favours women in New Brunswick ( 1 man, 13 women). This is probably an artefact of the case finding procedure and no particular importance will be attached to this observation.

\section{(b) Age of onset}

The average age of onset (Table 1) is approximately the same in all three groups, although more patients with the Acadian form (71\% vs $59 \%$ ) had onset after the age of eleven (Table 2). As will be discussed later, this observation may be of importance in determining the eventual progression of the disease.

\section{(c) Duration of illness}

Duration of illness appears to be essentially the same in the three groups studied. However, because of the slightly later age
Table 1: Symptom Scores and Demography

\begin{tabular}{|c|c|c|c|}
\hline & \multirow[b]{2}{*}{ Friedreich } & \multicolumn{2}{|c|}{ Acadian } \\
\hline & & New Brunswick & Louisiana \\
\hline $\mathrm{N}$ & 22 & 14 & 17 \\
\hline MALES & 10 & 1 & 7 \\
\hline FEMALES & 12 & 13 & 10 \\
\hline $\begin{array}{l}\text { AGE - } \\
\text { ONSET (yrs) }\end{array}$ & $10.2 \pm 0.9$ & $13.8 \pm 0.6$ & $10.5 \pm 0.8$ \\
\hline $\begin{array}{l}\text { AGE- } \\
\text { PRESENT (yrs) }\end{array}$ & $25.4 \pm 1.1$ & $28.1 \pm 1.7$ & $27.3 \pm 3.1$ \\
\hline $\begin{array}{l}\text { DURATION OF } \\
\text { ILLNESS (yrs) }\end{array}$ & $15.6 \pm 1.4$ & $14.4 \pm 1.5$ & $18.0 \pm 2.7$ \\
\hline $\begin{array}{l}\text { GAIT ATAXIA } \\
(\operatorname{Max} 3)\end{array}$ & $2.9 \pm 0.1$ & $2.1 \pm 0.2^{*}$ & $2.5 \pm 0.2^{*}$ \\
\hline $\begin{array}{l}\text { DYSARTHRIA } \\
(\operatorname{Max} 3)\end{array}$ & $2.1 \pm 0.1$ & $1.4 \pm 0.2^{*}$ & $1.9 \pm 0.2$ \\
\hline $\begin{array}{l}\text { MUSCLE } \\
\text { WEAKNESS } \\
(\text { Max 6) }\end{array}$ & $4.4 \pm 0.9$ & - & $2.8 \pm 0.9^{*}$ \\
\hline $\begin{array}{l}\text { BABINSKI } \\
(\operatorname{Max} 6)\end{array}$ & $6.0 \pm 0.0$ & $4.3 \pm 0.7^{*}$ & $4.8 \pm 0.5^{*}$ \\
\hline $\begin{array}{l}\text { PES CAVUS } \\
(\operatorname{Max} 3)\end{array}$ & $2.2 \pm 0.2$ & $1.6 \pm 0.5$ & $1.1 \pm 0.2^{*}$ \\
\hline $\begin{array}{l}\text { SCOLIOSIS } \\
(\operatorname{Max} 3)\end{array}$ & $2.3 \pm 0.2$ & $1.6 \pm 0.4^{*}$ & $1.5 \pm 0.3^{*}$ \\
\hline $\begin{array}{l}\text { NYSTAGMUS } \\
(\operatorname{Max} 3)\end{array}$ & $1.1 \pm 0.2$ & $0.7 \pm 0.2$ & $0.9 \pm 0.2$ \\
\hline $\begin{array}{l}\text { VIBRATORY } \\
\text { SENSE (Max 6) }\end{array}$ & $5.3 \pm 0.3$ & $4.8 \pm 0.3$ & $4.4 \pm 0.5$ \\
\hline $\begin{array}{l}\text { VIBRATORY } \\
\text { SENSE (in secs) } \\
\text { (normal > } 11 \text { secs) }\end{array}$ & $6.3 \pm 1.1$ & $8.3 \pm 1.2^{*}$ & $10.2 \pm 1.6^{*}$ \\
\hline $\begin{array}{l}\text { KNEE JERKS } \\
(\operatorname{Max} 12)\end{array}$ & $-12.0 \pm 0.0$ & $-12.0 \pm 0.0$ & $-12.0 \pm 0.0$ \\
\hline
\end{tabular}

*SIGNIFICANTLY DIFFERENT FROM FRIEDREICH

$(\rho<0.05$ at least (Student's T test)

\begin{tabular}{crrrr}
\hline Table 2: Age of Onset & \multicolumn{3}{c}{} \\
\hline \hline & \multicolumn{2}{c}{ FRIEDREICH'S } & \multicolumn{2}{c}{ ACADIAN } \\
AGE OF ONSET RANGE & \multicolumn{2}{c}{ ATAXIA } & \multicolumn{2}{c}{ ATAXIA } \\
& $(\mathbf{N})$ & $(\%)$ & $(\mathbf{N})$ & $(\%)$ \\
TOTAL & 22 & 100 & 31 & 100 \\
$0-5$ & 2 & 9 & 0 & 0 \\
$6-10$ & 7 & 32 & 9 & 29 \\
$11-15$ & 12 & 55 & 18 & 58 \\
$16-20$ & 1 & 4 & 4 & 13
\end{tabular}

of onset in many Acadian patients the present age is higher in the latter cases. In fact, the oldest Friedreich in this series is 34 years old, the youngest 17 , while in the Acadians the oldest is 45 , the youngest 9 . Nine of the 31 Acadians (29\%) are older than 34 (the oldest age observed in our Friedreich's series). This is probably the most important difference between the groups. 


\section{B. The Symptoms}

\section{(a) Incoordination:}

Incoordination is the predominant symptom in Friedreich's patients and Acadians cases. It is particularly evident as gait ataxia. As seen in Table 1, this ataxia is significantly milder in the Acadian group when average values are considered. The actual distribution of the severity of gait ataxia is seen in Table 3. A much higher proportion of Friedreich's cases (91\% vs $52 \%$ ) are classified as severe, or grade 3 , which is translated clinically into the inability to walk. This observation, taken together with the higher present age of the Acadians, indicates that these patients have less gait ataxia, at any given age, than the Friedreich's patient of similar age. However, as illustrated in Fig. 1, the rate of progression of incoordination (as a total score) is identical in both groups, the Acadians living out a longer segment of this progression curve.

\section{(b) Areflexia}

In Friedreich's Ataxia a total absence of deep tendon reflexes in the lower limbs (knee jerk and achilles tendon) is found from the very earliest diagnosis of ataxia and even some years before (Barbeau, 1982). In the present series of cases (Table 1), tendon reflexes could not be elicited in a single Friedreich's patient, even with reinforcement. Similarly, in the Acadian cases, deep tendon reflexes were always absent at the knees and ankles with standard tapping. However in 3 of the 31 cases, the Jendrasik maneuver of reinforcement permitted a flicker of a response in the knee jerks. These patients were the ones with the least decrease in vibratory sense(see infra).

(c) Dysarthria is slightly less severe as an average score (Table 1) in Acadian patients. It is, however, very similar in form to the

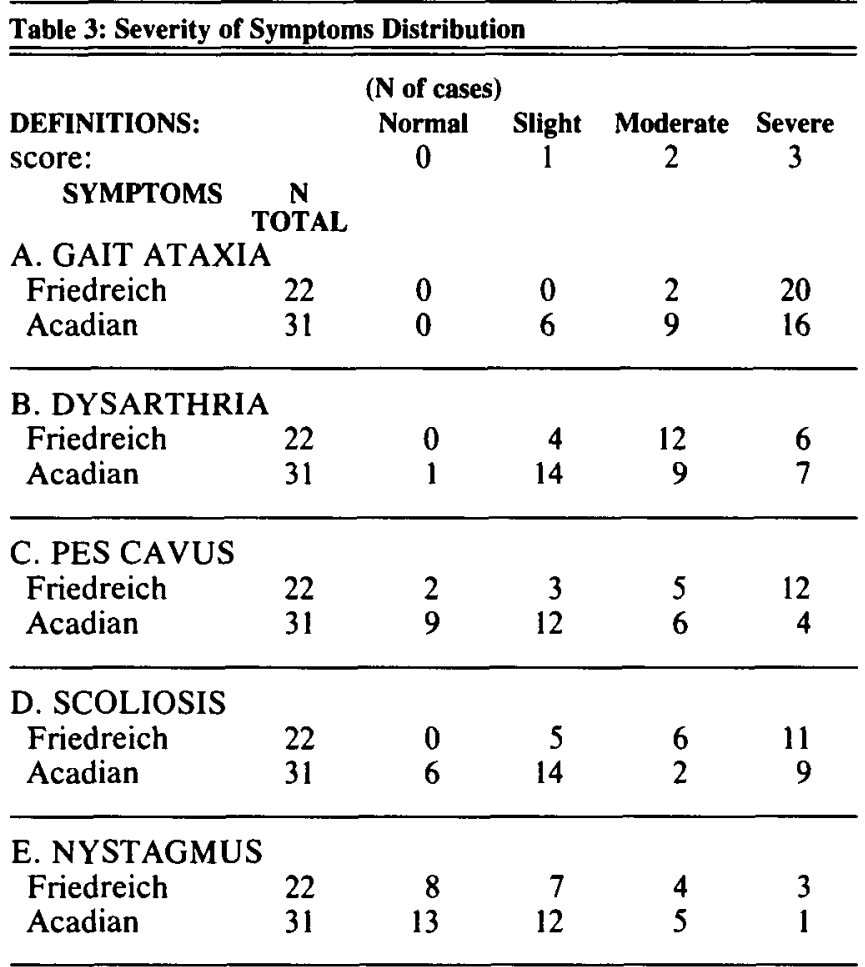

dysarthria of Friedreich's disease as described by Brown (1970). As seen in Table 3, the dysarthria of Acadians is mostly slight or moderate, as it is in Friedreich's disease.

(d) Peripheral signs: muscle weakness was always more severe in the Friedreich's patients than in the Acadians when it was recorded objectively, although it was present to some degree in every patient examined. The severity of muscle weakness, particularly at the hip girdle, was closely correlated with the ability to walk unaided.

Muscle atrophy, in both entities, is a very late phenomenon seen only in far advanced cases and true fasciculations are very rarely, if ever, encountered. Occasional facial myokymias can be observed in some patients with Friedreich's ataxia.

All the above signs and others, are grouped into the "Symptom Complex" giving the "Peripheral Involvement Score". As seen in Fig. 2 the evolution of peripheral involvement in both the Friedreich and Acadian forms follows the same curve for the first 10-12 years of evolution of the disease. Thereafter the courses diverge. Whereas Friedreich's disease progresses relentlessly as far as peripheral signs are concerned, there appears to be a slow-down in the peripheral involvement of Acadians after this period of evolution.

This same trend is objectively evidenced through the study of vibratory perception times (Fig. 3). For the first 10-12 years of evolution there is a sharp decline in the duration of perception (in secs). In Friedreich's disease the slope of the decline persists until zero values are attained (after 14 to 28 years of evolution). In Acadians, on the other hand, the slope noticeably changes and the rate of decline clearly slows down, or even stops. In some Acadian patients, even after 16 years of evolution, vibratory sense as measured by the tuning fork $(128 \mathrm{cps})$ remains entirely normal, i.e. above 11 seconds.

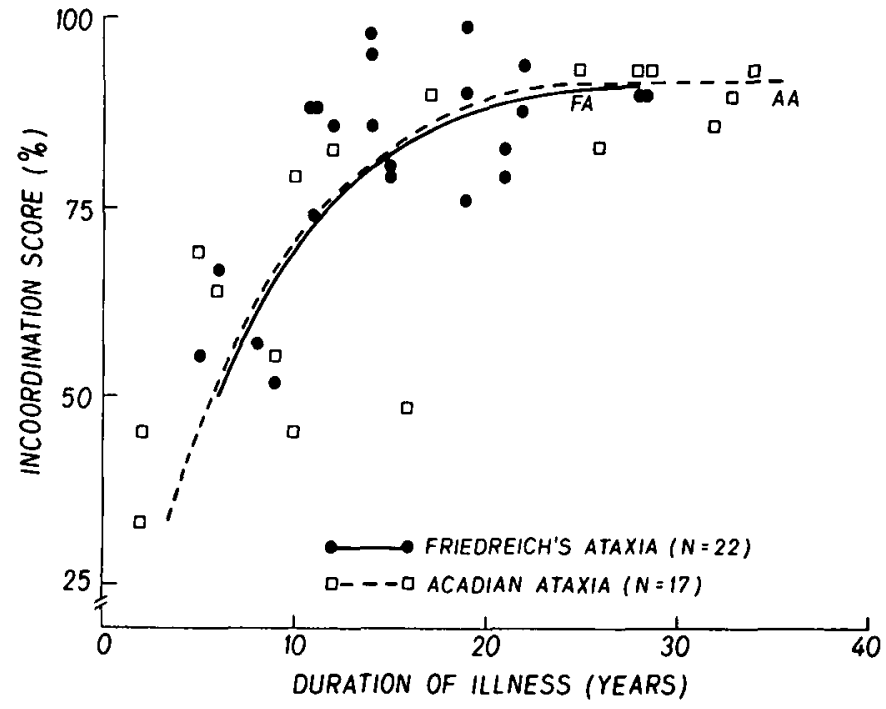

Figure 1-Evolution of the "Incoordination Score" as a function of illness duration. The incoordination score is normalized to $100 \%$ as explained in methods. The 17 cases of Acadian ataxia are from Louisiana "Cajuns". 
EVOLUTION OF PERIPHERAL INVOLVEMENT AS A FUNCTION OF ILLNESS DURATION

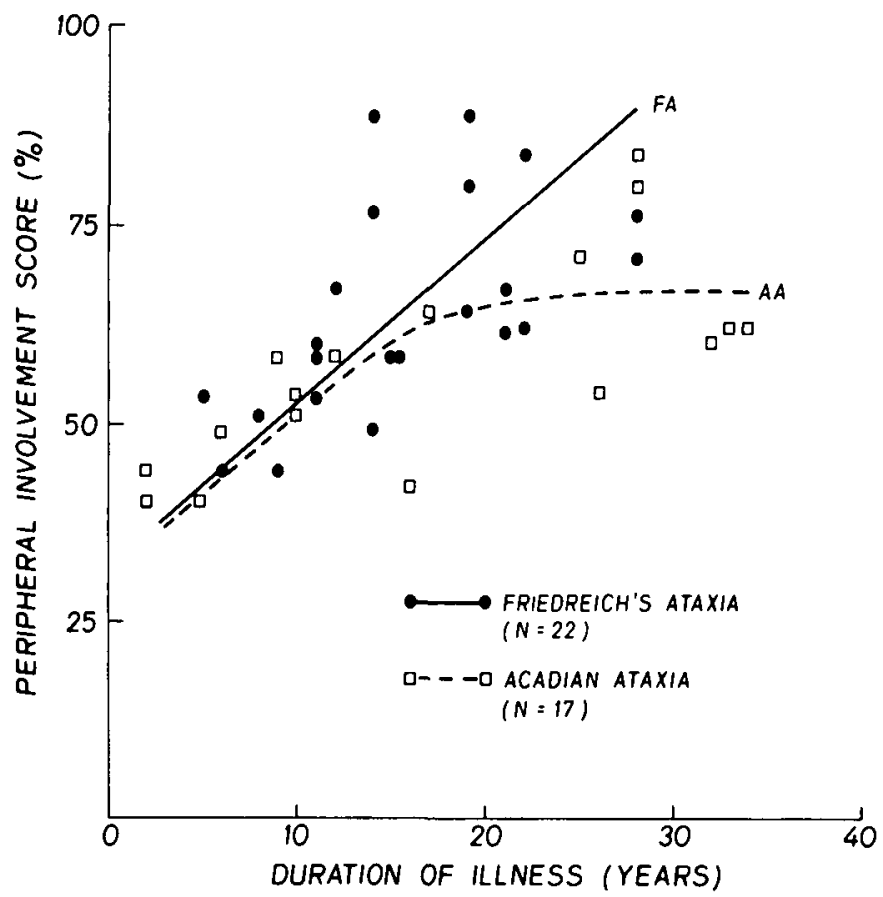

Figure 2 - Evolution of the "Peripheral Involvement" score as a function of illness duration. The peripheral score is normalized to $100 \%$ as explained in methods.

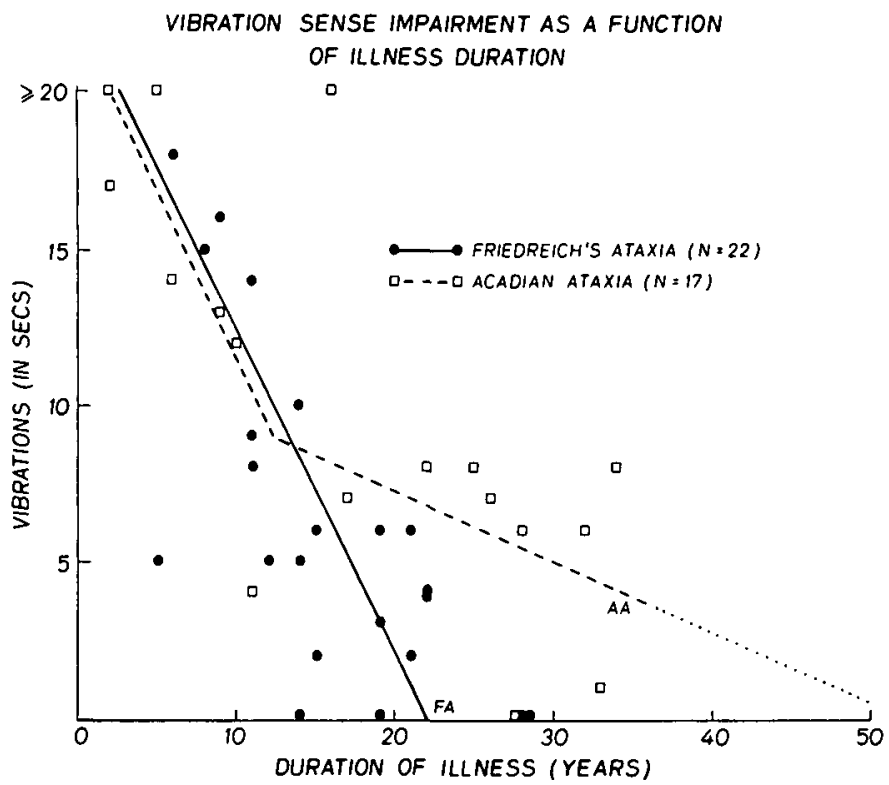

Figure 3 - Vibratory sense perception as a function of illness duration. Vibratory sense is measured with a 128 cps tuning fork at the malleola (ankle). Total time of perception of the vibration in both legs is recorded in seconds. A normal value is greater than 11 seconds in each leg.

\section{(e) Plantar responses}

A frank Babinski sign was seen bilaterally in $100 \%$ of our patients with Friedreich's disease. This is clearly not the case (Table 1) in the Acadian subjects. 2 of the 31 patients had bilateral normal flexor responses, and in a further 8 cases the response was bilaterally equivocal, at best. Thus a frank bilateral Babinski sign was only observed in $68 \%$ of the latter cases. As seen in Fig. 4, there was a clear correlation between duration of the illness and development of the extensor response. Whereas in Friedreich's disease, pyramidal signs appear very early (and always before two years of evolution), in Acadian ataxia this seems to be a much later, and progressive, development taking up to 15 to 20 years.

(f) Pes cavus is usually present, and often severe, in cases of Friedreich's disease. In our series $55 \%$ of these patients had a grade III bilateral pes cavus. Only 4 of the 31 Acadian cases (13\%) were so graded, and a full $29 \%$ had no malformation of the foot.

(g) Scoliosis follows essentially the same pattern. Whereas scoliosis is moderate $\left(>20^{\circ}\right)$ or severe $\left(>40^{\circ}\right)$ in $77 \%$ of Friedreich's disease patients, it is slight $\left(10-20^{\circ}\right)$ or absent in fully $65 \%$ of Acadian patients (Table 3). Again the marked difference between the two groups is in the further evolution and progression of this scoliosis. In Friedreich's disease (Fig. 5) the progression of the scoliosis is relentless for at least 25 years, with a peak in the pubertal years around age 11 (Allard et al., 1982). Interestingly after 10-15 years of observed evolution, which until then parallels that of Friedreich's disease, the progression of scoliosis in Acadian patients tapers off and occasionally appears to stop.

\section{(h) Nystagmus}

In contrast to the above symptoms and signs, there does not seem to be any difference in the development, and severity, of the nystagmus between the two forms of ataxia (Table 3).

EVOLUTION OF THE BABINSKI RESPONSE AS A FUNCTION OF ILLNESS DURATION

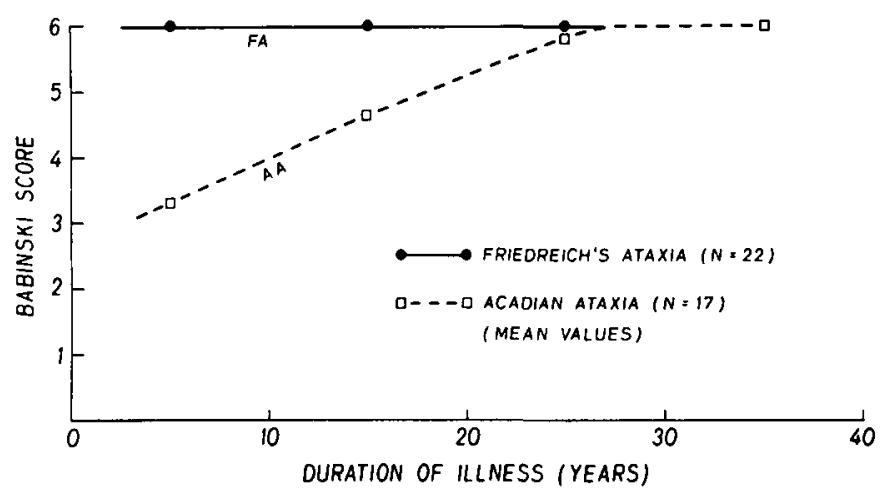

Figure $4-$ Evolution of the Babinski plantar response as a function of illness duration. A normal (flexor) plantar response is scored 0 . An equivocal response is scored 1 . An upward movement of the big toe without fanning of the other toes is scored 2. A full response is scored 3. The score given is the average for the two feet. 
EVOLUTION OF SCOLIOSIS AS A FUNCTION OF ILLNESS OURATION

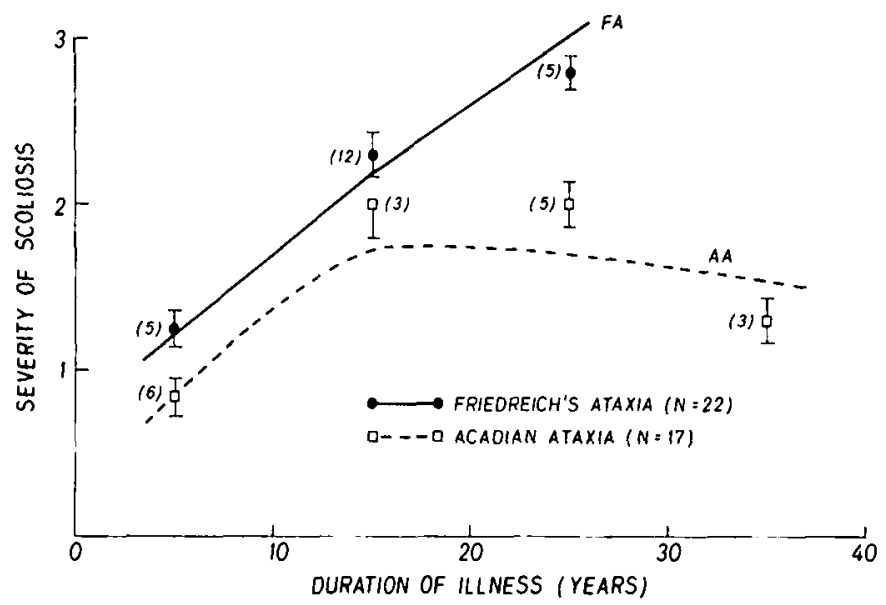

Figure 5 - Evolution of scoliosis as a function of illness duration. The severity of scoliosis is scored 0 for $0^{\circ}$ to $10^{\circ} ; 1$ for $10^{\circ}$ to $20^{\circ} ; 2$ for $20^{\circ}$ to $40^{\circ}$, and 3 for scoliosis above $40^{\circ}$. The figures are mean \pm S.E.M.

\section{(i) Cardiomyopathy}

Cardiac involvement is an important feature of Friedreich's disease, a hypertrophic cardiomyopathy being the rule, particularly after proper investigation with vecto and echocardiograms (Coté et al., 1976). Unfortunately, the very nature of our investigations involving field work, except for the Friedreich's patients, makes it impossible for us to conclude on this important point. Vecto and/or echocardiograms in our 22 patients with Friedreich's disease were positive for a hypertrophic cardiomyopathy $73 \%$ of the time. In the patients with Acadian ataxia where these tests were done, positivity for a cardiomyopathy was found in only $16 \%$ of cases. These figures, however, are tentative and should be confirmed by more specific studies.

\section{Discussion}

Acadians, and their descendants in Louisiana called the "Cajuns", do not originate from the same group of Frenchmen that populated the Province of Quebec and the banks of the Mississippi River. Acadia remained a separate colony from "Canada" between 1604 and 1713, although it often had the same governor. Exchanges between the two groups were limited to the "coureurs des bois". Acadia fell under English rule in 1713 and by 1755 the tensions were such that a major deportation of the French speaking Acadians was ordered. In Quebec (Lower Canada) the English won the war in 1760 but, in a remarkable feat of survival and pride by the "habitants", French remains the prevalent language to this day. To further distinguish between the two groups, the environment and surrounding gene pools could not be more different. The climates, and foods, of Quebec and Louisiana are of two poles. The same can be said for New Brunswick and Louisiana. In the North (former Acadia), the Acadians were surrounded by people of Scottish, Irish and Amerindian extraction. In Louisiana, the "Cajuns" have lived among Spaniards, Blacks, Germans and white Americans, thus two markedly different surrounding gene pools.
Despite such separate evolutions over a period of more than 200 years, it is remarkable that the very characteristic of slower progression which marked the ataxic cases (all of a recessive hereditary pattern) that we observed in New Brunswick and the Gaspé Peninsula, was found intact among the Louisiana Cajuns. The similarities are such that no significant differences could be demonstrated between the two groups of Acadian descent, (Table 1) and it was permissible to pool them for further study.

This observation is strenghtened by the preliminary results of genealogical studies. As seen in Fig. 6 we have been able to trace back the origin of two of our Canadian "Acadian" cases to a certain number of ancestral couples. Of the 12 couples common to these two independent Canadian families, one (J.H. and M.J.) also appears to be the common ancestral couple of the Cajun cases studied in Louisiana. This last information comes from the painstaking investigatory work of Mrs. Betty LeBlanc of Texas who was kind enough to lend us her documents. If this observation is confirmed by further work, it will be a very important further argument in favour of a common entity afflicting ataxic patients of New Brunswick and Louisiana.

Is this "Acadian ataxia", as we have termed it, different from Friedreich's disease? This is of course the reason for the present report. Our 22 cases of Friedreich's disease conform in all points to the criteria for "classical" cases defined in 1976 by Geoffroy et al. and since adhered to by most researchers. We are thus dealing with a homogeneous group of cases which serve as our controls. On the other hand, the Acadians show certain constant characteristics that differentiate them from true Friedreich's disease (Table 4): the main dissimilarities are in the rate of progression of the cardinal symptoms. This is evident in the early as well as in the late phases of the disease. Thus pes cavus is much less frequent within the first 10 years of

Table 4: Cardinal Symptoms and Signs

$$
\% \text { of cases }
$$

FRIEDREICH'S

ACADIAN ATAXIA

$(\mathrm{N}=22)$

$(\mathrm{N}=31)$

A. OBLIGATORY SIGNS

$$
\text { 1. ONSET BEFORE AGE } 20
$$

100

100

2. ATAXIA OF GAIT

100

100

3. PROGRESSION OF

ATAXIA in last 2 years

100

83.6

4. DYSARTHRIA

100 100

5. DECREASE IN VIBRATORY SENSE

100

6. MUSCLE WEAKNESS

100

7. AREFLEXIA IN LOWER LIMBS

100

100

B. PROGRESSIVE SIGNS 1. BABINSKI SIGN
(FRANK)

100

67.7

2. PES CAVUS (EVIDENT)

77.3

32.3

3. SCOLIOSIS $\left(>10^{\circ}\right)$

77.3

35.5

4. CARDIOMYOPATHY

(E.C.G. + ECHO) 


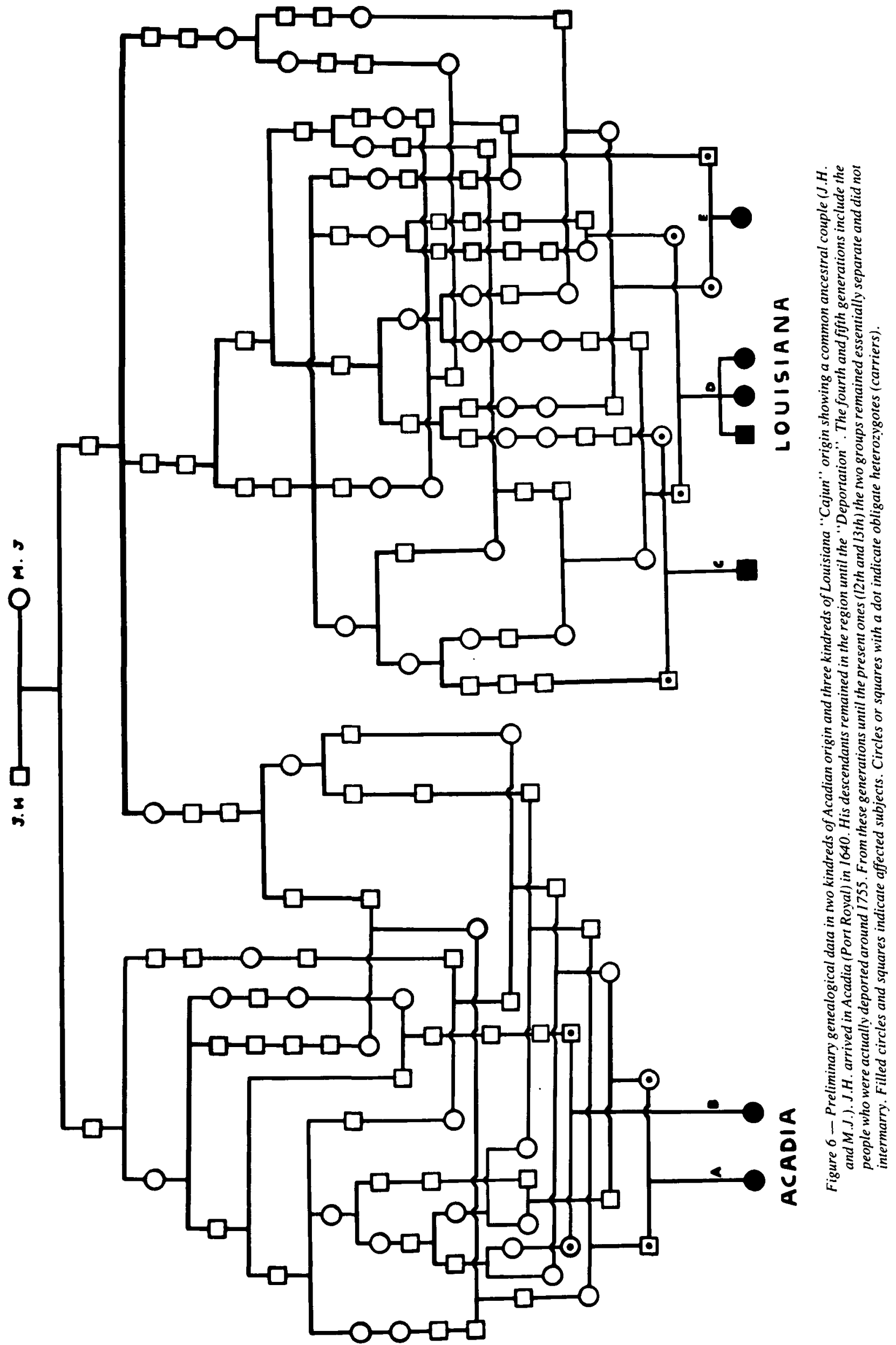


evolution. Pyramidal involvement, as evidenced by extensor plantar responses (Babinski signs) takes much more time to be manifested, many years more in fact than the obligatory maximum period of two years for the appearance of the sign in Friedreich's disease. The same is true for the start of posterior column damage, as evidenced by the duration of vibratory perception at the ankle. All these slower events result in a slightly later apparent age of onset of the ataxic symptoms.

But the most impressive difference between the two entities occurs after about 10 years of an evolution which, hitherto, had been basically parallel, if slower. After this relentless period of evolution, the Acadian ataxics note a marked decrease in the extent of progression of the peripheral involvement, such as muscle weakness, loss of vibratory perception and even scoliosis. The rate of increase in gait ataxia, however, remain identical in both groups, the Acadians living longer to complete the progression curve of ataxia (Fig. 1). Although our data on this point is still too preliminary, it appears that the Acadians experience a later onset of the cardiomyopathy with less severe consequences, or can even occasionally avoid it entirely. This very cardiomyopathy may be an important contributing factor to the rate of progression in later years in "classical" 'Friedreich's disease.

Because the major difference in evolution between the two entities occurs after 10-12 years of apparent disease, thus generally at the end of the pubertal or growth period of the organism, one can postulate that this difference is the result of a superimposed hormonal defect in cases of "classical" Friedreich's disease. In these patients the metabolic and cardiac consequences of this added defect are such that the nervous system is incapable of partial recovery after the end of the growth period, and the declining course becomes irreversible. In Acadians, the normal course of the ataxic (spinocerebellar) disease is carried out to the end, with few complications.

It would thus appear that Acadian ataxia is a slower progressing and less severe form of the recessive ataxia of Friedreich. The shape of the progression curve of the ataxic part is identical over time for the two groups. The Acadians just live longer. Moreover the disease seems to be a much purer form of spinocerebellar involvement in Acadians, less encumbered by apparently secondary events (cardiomyopathy, scoliosis, metabolic imbalances) which determine the extent of the damage to other pathways and systems, including pyramidal tract involvement, such multiple involvement modulating the rate of decline.

What remains to be decided, and studied, is whether the two entities as we observe them are two facets in the clinical spectrum of the same disease, two allelic disorders, or two clearly genetically distinct diseases. The answer to this question will only come from more advanced biochemical investigations to be carried out in these patients. For the time being we propose that the pathophysiology of the ataxic component is the same in both disorders, but that the disorders differ in the presence of an added modifyer of hormonal nature. These two entities should be regarded as distinct for the time being, and particularly for the purpose of doing research.

In the real world, of course, cases of "classical" Friedreich's ataxia and "Acadian-type" ataxia will be found at random. Until we have a biochemical marker, it is most likely that the two forms will be confused by all physicians not exposed to many ataxic patients and even by researchers. This may be one of the reasons behind the variability of results between different laboratories. It is hoped that the present study, by better defining these entities, will help clarify these issues.

\section{ACKNOWLEDGEMENTS}

The authors would like to thank the National Ataxia Foundation which sponsored the Lafayette Clinic; Mrs. B. LeBlanc, D. Hightower and D. Drake who organized it, and the numerous volunteers and patients who participated. The studies by the senior authors were supported by a grant from L'Association Canadienne de l'Ataxie de Friedreich. Thanks are also due to Miss I. Morin and Mr. O Taliano for the illustrations, to Miss S. Paris, R.N. for record keeping and to Mrs. $\mathrm{N}$. Guay-Poirier for typing the manuscript.

\section{REFERENCES}

Allard P, Dansereau J. Thiry PS, Geoffroy G, Raso JV, Duhaime M (1982) Scoliosis in Friedreich's Ataxia. Can J Neurol Sci 9: 105-111.

Arsenault B (1978) Histoire et généalogie des Acadiens. In: Histoire des Acadiens, vol 1 Lemeac, Montreal, pp 1-389.

Barbeau A (1980) Distribution of ataxia in Quebec. In: SpinoCerebellar Degeneration I. Sobue (ed) Tokyo University Press, pp 120-142.

Barbeau A (1982) Friedreich's Disease 1982: Etiologic hypotheses: A personal analysis. Can J Neurol Sci 9: 243-263.

Bouchard JP, Barbeau A, Bouchard R, Paquet M, Bouchard RW (1979) A cluster of Friedreich's ataxia in Rimouski, Quebec Can J Neurol: Sci 6: 205-208.

Brown JR (1970) Ataxic dysarthria. Int J Neurol 7: 302-318.

Cote M, Davignon A, Pecko-Drouin K, Solignac A, Geoffroy G, Lemieux B, Barbeau A (1976) Cardiological signs and symptoms in Friedreich's ataxia. Can J Neurol Sci 3: 319-322.

Geoffroy G, Barbeau A, Breton G, Lemieux B, Aube M, Leger C, Bouchard JP (1976) Clinical description and roentgenologic evaluation of patients with Friedreich's ataxia. Can J Neurol Sci 3: 279-286.

Harding AE (1981) Early onset cerebellar ataxia with retained tendon reflexes: a clinical and genetic study of a disorder distinct from Friedreich's ataxia. J Neurol Neurosurg Psychiat 44: 503-508.

Pourcher E, Barbeau A (1980) Field testing of an ataxia scoring and staging system. Can J Neurol Sci 7: 339-344. 